БІОЛОГІя

BIOLOGY

https://doi.org/10.15407/dopovidi2021.06.120

УДК 57.086.13:577.352.4:611.018.51:544.722.14

О.О. Чабаненко, https://orcid.org/0000-0003-1977-3495

Н.В. Орлова, https://orcid.org/0000-0001-6569-9906

Н.М. Шпакова, https://orcid.org/0000-0002-0148-7522

Інститут проблем кріобіології і кріомедицини НАН України, Харків

E-mail: chabanenkoolena@gmail.com

\title{
Тестування стану еритроцитів людини після сумісної дії постгіпертонічного шоку та амфіфільних сполук
}

Представлено академіком НАН Украйни А.М. Гольщевим

Досліджено вплив температури на стан еритроцитів, які збереглися після сумісної дї постгіпертонічного шоку (ПГШ) та амфіфільних сполук. Із залежностей постгіпертонічного гемолізу еритроцитів від концентрації амфіфільної сполуки $\left(0^{\circ} \mathrm{C}\right)$ визначено ефективні концентрації (високі) та концентрації, що відповідають початку плато (низькі). Встановлено, що в разі використання аніонного децилсульфату натрію в обох концентраціях клітини, які збереглися після дї ПГШ та амфіфільної сполуки, виявляють стійкість до підвищення температури (із діапазону від 10 до $37^{\circ} \mathrm{C}$ ). У випадку застосування катіонного трифторперазину і неіонного дещил- $\beta, D$-глюкопіранозиду у високих конщентращіях еритроцити чутливі до нагрівання, а в низьких - стійкі. Отже, для всіх досліджуваних речовин є можливість підібрати з плато таку конщентрацію, за якої клітини будуть зберігати свою чілісність під час нагрівання.

Ключові слова: постгіпертонічний шок, еритроцити людини, амфіфільні сполуки, температура.

Наразі запаси донорської крові в Україні істотно обмежені через зменшення кількості донорів, поширення хвороб, що передаються кров’ю, та збільшення попиту на неї за умов надзвичайних ситуацій [1]. Постійну доступність і довгострокове зберігання еритроцитів людини забезпечує їх кріоконсервування за низьких температур [2]. Для вивчення факторів пошкодження, які діють на етапі розморожування еритроцитів, як модель використовується постгіпертонічний шок (ПГШ) [3]. Для здійснення ПГШ клітини переносять із гіпертонічних в ізотонічні розчини.

Нещодавно проведеними експериментальними дослідженнями встановлено низку амфіфільних сполук, які за умов ПГШ еритроцитів здатні знижувати рівень гемолізу клітин за

Ц и т у в а н н я: Чабаненко О.О., Орлова Н.В., Шпакова Н.М. Тестування стану еритроцитів людини після сумісної дії постгіпертонічного шоку та амфіфільних сполук. Допов. Наи. акад. наук Укр. 2021. № 6. C. 120-125. https://doi.org/10.15407/dopovidi2021.06.120 
температури $0{ }^{\circ} \mathrm{C}[4,5]$. Доцільно було б дослідити стан клітин, які збереглися за вищезазначених умов. Оскільки амфіфільні сполуки виявляли антигемолітичний ефект за умов ПГШ еритроцитів тільки за низької температури $\left(0^{\circ} \mathrm{C}\right.$ на відміну від $\left.37^{\circ} \mathrm{C}\right)$, тому як тест на бар'єрні властивості еритроцитарних мембран варто застосувати підвищення температури від $0{ }^{\circ} \mathrm{C}$ до значень із діапазону $10-37^{\circ} \mathrm{C}$.

Ми ставили за мету вивчити вплив температури на стан еритроцитів людини, які збереглися після сумісної дії ПГШ та амфіфільних сполук, що належать до різних класів поверхнево-активних речовин.

Матеріали та методи. Для дослідження використовували еритроцити, отримані зі свіжозібраної крові чоловіків групи А (II) ${ }^{+}$Еритроцити одержували методом центрифугування цільної крові при 3000 об/хв (центрифуга ОПн-3У4.2 “Дастан”, Киргизстан) протягом 3 хв у 10-кратному об'ємі фізіологічного розчину (0,15 моль/л NaCl, 5 ммоль/л фосфатний буфер, pH 7,4) з подальшим видаленням плазми і лейкоцитарного шару.

ПГШ еритроцитів здійснювали шляхом ізотермічного перенесення еритроцитів 3 гіпертонічного розчину (середовище дегідратації; 1,65 моль/л $\mathrm{NaCl}, 5$ ммоль/л фосфатний буфер, pH 7,4) в ізотонічний розчин (середовище регідратації; 0,15 моль/л $\mathrm{NaCl}, 5$ ммоль/л фосфатний буфер, $\mathrm{pH} 7,4)$ за температури $0{ }^{\circ} \mathrm{C}$. Тривалість інкубування еритроцитів у середовищах дегідратації становила 20 хв, регідратації - 5 хв [3]. Для оцінки стану еритроцитів, які збереглися після дії ПГШ і амфіфільних сполук за температури $0{ }^{\circ} \mathrm{C}$, клітинну суспензію нагрівали і витримували 30 хв у водяній ванні за різних значень температури 3 діапазону $10-37^{\circ} \mathrm{C}$ з кроком $10{ }^{\circ} \mathrm{C}$.

У дослідженні використовували амфіфільні сполуки, які належать до різних класів поверхнево-активних речовин: катіонних - трифторперазин (ТФП), аніонних - децилсульфат натрію (C10); неіонних - децил- $\beta, \mathrm{D}$-глюкопіранозид (ДГП). Амфіфільні речовини додавали в середовище регідратації перед внесенням у нього клітин [6].

Вміст кількості гемоглобіну, який вийшов у супернатант, визначали спектрофотометрично на СФ-4А у проточній кюветі на довжині хвилі 543 нм. Кінцевий гематокрит становив 0,4%. За 100 \% приймали поглинання у зразку, в який додавали детергент тритон Х-100 у концентрації 0,1\%.

Статистичну обробку отриманих експериментальних результатів проводили за допомогою програми “Statistica 6.0” (“StatSoft Inc.”, США). Експериментальні дані представлені у вигляді медіани (Me). Статистичну значущість відмінностей досліджуваних числових показників перевіряли з використанням T-критерію Вілкоксона. Відмінності вважали значущими при $p \leqslant 0,05$.

Результати та обговорення. У результаті дослідження впливу амфіфільних сполук, які належать до різних класів поверхнево-активних речовин, на постгіпертонічний гемоліз еритроцитів були отримані залежності гемолізу еритроцитів від концентрації речовини в середовищі регідратації за температури $0{ }^{\circ} \mathrm{C}$ [4].

На рис. 1 наведена типова залежність постгіпертонічного гемолізу еритроцитів від концентрації C10 у середовищі регідратації. Видно, що концентраційна залежність характеризується наявністю трьох ділянок. Зі збільшенням концентрації С10 поступово знижується рівень пошкодження клітин, після чого залежність виходить на плато і з подальшим підвищенням концентрації амфіфілу постгіпертонічний гемоліз еритроцитів зростає. 


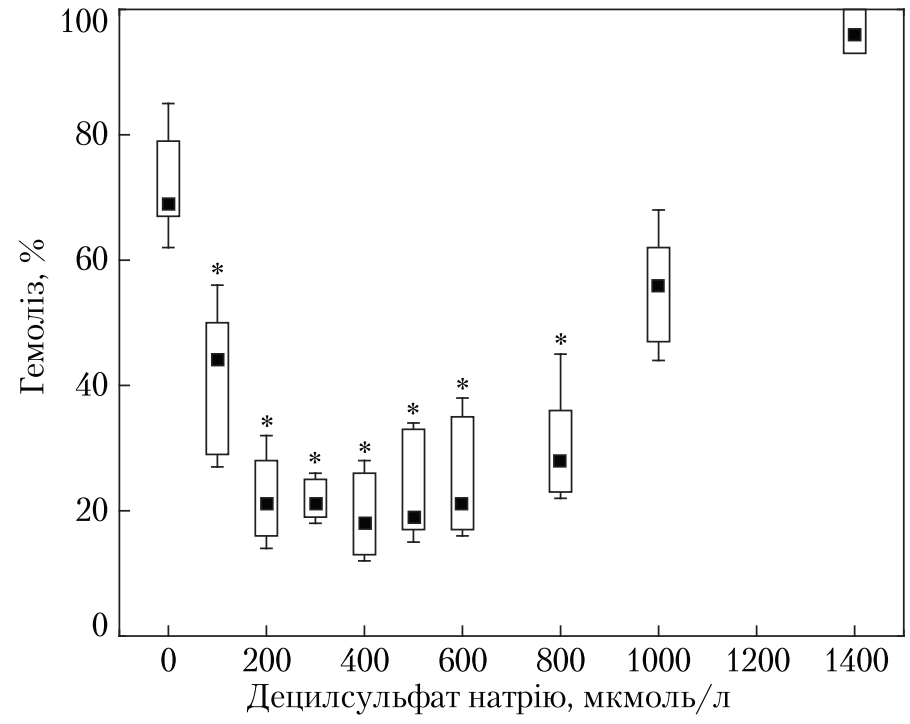

Puc. 1. Залежність рівня постгіпертонічного гемолізу еритроцитів людини від концентрації С10 у середовищі регідратації $\left(0{ }^{\circ} \mathrm{C}\right)$. - медіана; $\square$ - інтерквартильний інтервал (Q1-Q3); I - максимальне та мінімальне значення. * - статистично значущі відмінності порівняно з результатами за відсутності амфіфільної сполуки $(p<0,05)$

Для кількісної оцінки ефективності досліджених амфіфільних сполук (С10, ТФП, ДГП) за умов ПГШ еритроцитів з отриманих залежностей визначали розміри плато і значення ефективних концентрацій, які відповідають середині плато [4]. Грунтуючись на цих даних, для подальших досліджень було вибрано дві концентрації амфіфільних сполук - ефективна і концентрація, яка відповідає початку плато.

Клітини піддавали дії ПГШ у присутності амфіфільної сполуки у відповідній концентрації за температури $0{ }^{\circ} \mathrm{C}$. Частина еритроцитів лізувала, а ті клітини, що збереглися, піддавали нагріванню. На рис. 2 наведені результати впливу температури на рівень гемолізу клітин, які збереглися після дії ПГШ за температури $0{ }^{\circ} \mathrm{C}$ у разі використання амфіфільних сполук в ефективних концентраціях. За цим показником амфіфіли значно відрізняються. Так, для ТФП, С10 і ДГП ефективні концентрації становлять 150, 400 і 600 мкмоль/л відповідно. Контролем були еритроцити, піддані дії ПГШ без використання амфіфілів за різних значень температури. Видно, що рівень гемолізу контрольних клітин практично не залежить від температури.

За умов дії ТФП розвиток гемолізу еритроцитів спостерігається за температури $20^{\circ} \mathrm{C}$ і вище, у разі ДГП нагрівання призводить до лізису клітин тільки за температури $37{ }^{\circ} \mathrm{C}$. У варіанті застосування С10 рівень гемолізу клітин становить 10 \% і не залежить від температури.

Таким чином, виявлено, що еритроцити, які збереглися після дії ПГШ у присутності ТФП і ДГП, чутливі до підвищення температури, а сполука С10 забезпечує стійкість клітин до подальшого нагрівання.

За умов ПГШ еритроцитів ефективність речовин, найвірогідніше, обумовлена їх здатністю вбудовуватися в мембрану в місці формування дефектів і у такий спосіб значно збільшувати критичний гемолітичний об’єм клітин, запобігаючи їх руйнуванню. Ймовірно, С10 перешкоджає процесу реорганізації еритроцитарної мембрани, який відбувається у разі підвищення температури, i, як наслідок, запобігає розвитку трансмембранної гемолітичної пори.

У наступному експерименті, умови проведення якого аналогічні попередньому, амфіфільні сполуки застосовували в концентраціях, нижчих за ефективні. Отримані результати наведені на рис. 3. Видно, що у разі застосування амфіфільних сполук у концентраціях, які 

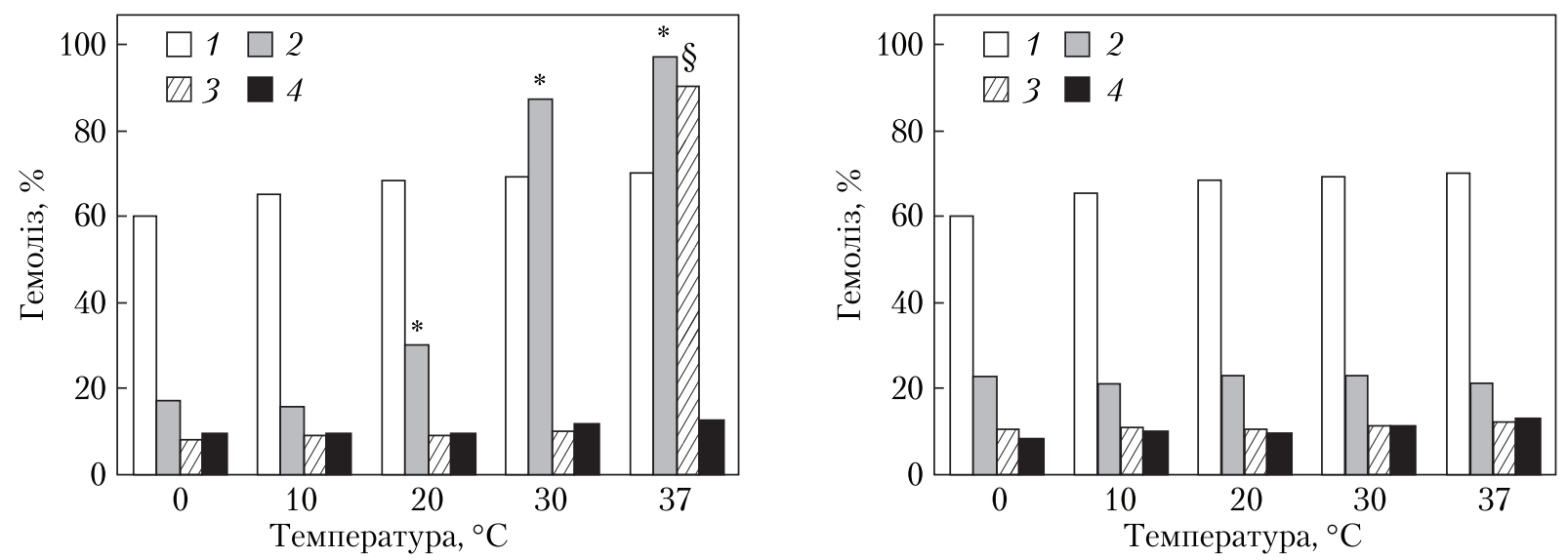

Puc. 2. Вплив температури (від 0 до $37^{\circ} \mathrm{C}$ ) на гемоліз еритроцитів людини, які збереглися після дії ПГШ у присутності амфіфільних сполук, в ефективних концентраціях. 1 - контроль; 2 - ТФП, 150 мкмоль/л;

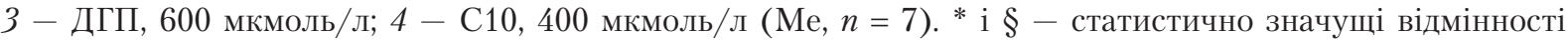
порівняно з результатами, отриманими за температури $0{ }^{\circ} \mathrm{C}$ із застосуванням ТФП і ДГП відповідно $(p<0,05)$

$\boldsymbol{P u c . 3 . ~ В п л и в ~ т е м п е р а т у р и ~ ( в і д ~} 0$ до $37^{\circ} \mathrm{C}$ ) на гемоліз еритроцитів людини, які збереглися після дії ПГШ у присутності амфіфільних сполук, в концентраціях, нижчих за ефективні. 1 - контроль; 2 - ТФП, 50 мкмоль/л; 3 - С10, 180 мкмоль/л; 4 - ДГП, 200 мкмоль/л (Ме, $n=7)$

відповідають початку плато відповідних концентраційних залежностей, нагрівання клітин до температур із діапазону $10-37^{\circ} \mathrm{C}$ не спричиняє додаткового їх пошкодження.

Таким чином, аналізуючи отримані результати, зазначимо, що для всіх досліджуваних амфіфільних речовин є можливість підібрати з плато таку концентрацію, за якої клітини будуть зберігати свою цілісність під час нагрівання.

Використані амфіфільні сполуки значно відрізняються за своїми фізико-хімічними властивостями. Так, позитивно заряджений ТФП переважно розподіляється у внутрішньому моношарі ліпідного бішару і спричиняє трансформацію еритроцитів за типом дискоцит-стоматоцит [7, 8]. Негативно заряджений С10 і неіонний ДГП переважно вбудовуються в зовнішній моношар ліпідного бішару еритроцитарної мембрани, в результаті чого еритроцити набувають форми ехіноцитів [9]. Виходячи з того, що всі ці речовини виявляють захисну дію за умов ПГШ еритроцитів $\left(0^{\circ} \mathrm{C}\right)$, можна вважати, що визначальним $\epsilon$ амфіфільність їх молекул $[10,11]$. Останнє обумовлює здатність речовин вбудовуватися в мембрану в місця формування дефектів і у такий спосіб значно збільшувати критичний гемолітичний об’єм клітин та, як наслідок, запобігати їх руйнуванню. Антигемолітичний ефект амфіфільних сполук за умов застосування у певних концентраціях зберігається навіть у разі значного підвищення температури.

Висновки. Тестування бар'єрних властивостей еритроцитарних мембран показало, що еритроцити, які збереглися після дії ПГШ у присутності ТФП і ДГП в ефективних концентраціях $\left(0{ }^{\circ} \mathrm{C}\right)$, чутливі до підвищення температури, а в низьких концентраціях (які відповідають початку плато відповідної концентраційної залежності) - стійкі до подальшого нагрівання. За цих умов у разі використання С10 в обох концентраціях еритроцити виявляють стійкість до подальшого нагрівання. 


\section{ЦИТОВАНА ЛІТЕРАТУРА}

1. Любич В.В. Виробництво препаратів донорської крові в Україні та контроль їхньої якості. Гематологія і переливання крові. 2017. Вип. 39. С. 99-104.

2. Lagerberg J.W. Frozen blood reserves. Cryopreservation and freeze-drying protocols. New York: Humana, 2021. P. 523-538. (Methods in molecular biology, vol. 2180). https://doi.org/10.1007/978-1-0716-0783-1_26

3. Семионова Е.А., Ершова Н.А., Ершов С.С., Орлова Н.В., Шпакова Н.М. Особенности проявления постгипертонического лизиса эритроцитов некоторых млекопитающих. Пробл. криобиологии и криомедицины. 2016. 26, № 1. C. 73-83. https://doi.org/10.15407/cryo26.01.073

4. Чабаненко Е.А., Ершова Н.А., Орлова Н.В., Шпакова Н.М. Влияние амфифильных соединений на постгипертонический шок эритроцитов человека. Вісн. Харків. нач. ун-ту ім. В.Н. Каразіна. Сер. Біол. 2019. Вип. 33. С. 84-90. https://doi.org/10.26565/2075-5457-2019-33-11

5. Chabanenko O.O., Yershova N.A., Shpakova N.M. Effect of amphiphilic compounds on posthypertonic lysis of erythrocytes. Probl. Cryobiol. Cryomed. 2020. 30, № 3. C. 286. https://doi.org/10.15407/cryo30.03.286

6. Семионова Е.А., Чабаненко Е.А., Орлова Н.В., Зубов П.М., Шпакова Н.М. К вопросу о механизме антигемолитического действия хлорпромазина в условиях постгипертонического шока эритроцитов. Пробл. криобиологии и криомедищиньь. 2017. 27, № 3. С. 219-229. https://doi.org/10.15407/cryo27.03.219

7. Коваленко С.Є., Алексєєва Л.І., Кулєшова Л.Г., Коваленко І.Ф., Холодний В.С., Гордієнко Є.О., Гордієнко О.І. Можливі механізми антигемолітичної дії хлорпромазину. Пробл. кріобіологіï. 2006. 16, № 2. C. $137-146$.

8. Manaargadoo-Catin M., Ali-Cherif A., Pougnas J.-L., Perrin C. Hemolysis by surfactant - a review. Adv. Colloid Interface Sci. 2016. 228. P. 1-16. https://doi.org/10.1016/j.cis.2015.10.011

9. Isomaa B., Hägerstrand H., Paatero G. Shape transformations induced by amphiphiles in erythrocytes. Biochim. Biophys. Acta. 1987. 899, № 1. P. 93-103. https://doi.org/10.1016/0005-2736(87)90243-4

10. Manisha mishra, Muthuprasanna P., Surya prabha K., Sobhita rani P., Satish babu I.A., Sarath Chandiran I., Arunachalam G., Shalini S. Basics and potential applications of surfactants - A review. Int. J. PharmTech Res. 2009. 1, № 4. P. 1354-1365.

11. Babajanzadeh B., Sherizadeh S., Ranji H. Detergents and surfactants: a brief review. Open Access J. Sci. 2019. 3, № 3. P. 94-99. https://doi.org/10.15406/oajs.2019.03.00138

Надійшло до редакції 19.07.2021

\section{REFERENCES}

1. Lyubych, V. V. (2017). The production of donor blood preparations in Ukraine and its quality control. Hematolohiia i perelyvannia krovi, Iss. 39, pp. 99-104 (in Ukrainian).

2. Lagerberg, J. W. (2021). Frozen blood reserves. In Cryopreservation and freeze-drying protocols. Methods in molecular biology, vol. 2180 (pp. 523-538). New York: Humana. https://doi.org/10.1007/978-1-0716-0783-1_26

3. Semionova, E. A., Yershova, N. A., Yershov, S. S., Orlova, N. V. \& Shpakova, N. M. (2016). Peculiarities of posthypertonic lysis in erythrocytes of several mammals. Probl. Cryobiol. Cryomed., 26, No. 1, pp. 73-83. https://doi.org/10.15407/cryo26.01.073

4. Chabanenko, O. O., Yershova, N. A., Orlova, N. V. \& Shpakova, N. M. (2019). Impact of amphiphilic compounds on post-hypertonic shock of human erythrocytes. Visn. Kharkiv. nats. un-tu im. V.N. Karazina. Ser. Biol., 33, pp. 84-90 (in Russian). https://doi.org/10.26565/2075-5457-2019-33-11

5. Chabanenko, O. O., Yershova, N. A. \& Shpakova, N. M. (2020). Effect of amphiphilic compounds on posthypertonic lysis of erythrocytes. Probl. Cryobiol. Cryomed., 30, No. 3, pp. 286. https://doi.org/10.15407/cryo30.03.286

6. Semionova, E. A., Chabanenko, E.A., Orlova, N. V., Zubov, P. M. \& Shpakova, N. M. (2017). About mechanism of antihemolitic action of chlorpromazine under posthypertonic stress in erythrocytes. Probl. Cryobiol. Cryomed., 27, No. 3, pp. 219-229. https://doi.org/10.15407/cryo27.03.219

7. Kovalenko, S. E., Alekseyeva, L. I., Kuleshova, L. G., Kovalenko, I. F., Kholodnyy, V. S., Gordiyenko, E. I. \& Gordiyenko, O. I. (2006). Possible mechanisms of chlorpromazine antihemolytic effect. Probl. Cryobiol., 16, No. 2, pp. 137-146. 
8. Manaargadoo-Catin, M., Ali-Cherif, A., Pougnas, J.-L. \& Perrin, C. (2016). Hemolysis by surfactant - a review. Adv. Colloid Interface Sci., 228, pp. 1-16. https://doi.org/10.1016/j.cis.2015.10.011

9. Isomaa, B., Hägerstrand, H. \& Paatero, G. (1987). Shape transformations induced by amphiphiles in erythrocytes. Biochim. Biophys. Acta, 899, No. 1, pp. 93-103. https://doi.org/10.1016/0005-2736(87)90243-4

10. Manisha mishra, Muthuprasanna, P., Surya prabha, K., Sobhita rani, P., Satish babu, I. A., Sarath Chandiran, I., Arunachalam, G. \& Shalini, S. (2009). Basics and potential applications of surfactants - A review. Int. J. PharmTech Res., 1, No. 4, pp. 1354-1365.

11. Babajanzadeh, B., Sherizadeh, S. \& Ranji, H. (2019). Detergents and surfactants: a brief review. Open. Access. J. Sci., 3, No. 3, pp. 94-99. https://doi.org/10.15406/oajs.2019.03.00138

Received 19.07.2021

O.O. Chabanenko, https://orcid.org/0000-0003-1977-3495

N.V. Orlova, https://orcid.org/0000-0001-6569-9906

N.M. Shpakova, https://orcid.org/0000-0002-0148-7522

Institute for Problems of Cryobiology and Cryomedicine of the NAS of Ukraine, Kharkiv

E-mail: chabanenkoolena@gmail.com

TESTING THE STATE OF HUMAN ERYTHROCYTES AFTER COMBINED ACTION OF POSTHYPERTONIC SHOCK AND AMPHIPHILIC COMPOUNDS

The effect of the temperature on the state of erythrocytes, which survived after the combined action of posthypertonic shock (PHS) and amphiphilic compounds, is studied. The effective concentrations (high) and concentrations corresponding to the beginning of the plateau (low) are determined from the dependences of posthypertonic hemolysis of erythrocytes on the concentration of amphiphilic compound $\left(0{ }^{\circ} \mathrm{C}\right)$. It is found that, when using anionic sodium decyl sulfate in both concentrations, the cells that survived after the action of PHS and amphiphilic compounds are resistant to the temperature rise (from 10 to $37^{\circ} \mathrm{C}$ ). When using cationic trifluoroperazine and nonionic decyl- $\beta, \mathrm{D}$-glucopyranoside in high concentrations, the erythrocytes have been shown to be sensitive to heat, and in low ones - resistant. Therefore, for all tested substances, the selection from the plateau of such a concentration at which the cells will maintain their integrity when heated is possible.

Keywords: posthypertonic shock; human erythrocytes; amphiphilic compounds, temperature. 